\title{
The analysis of the emission level from a heavy-duty truck in city traffic
}

\author{
The paper presents the analysis of the emission level from a heavy-duty truck of the GVW of $12000 \mathrm{~kg}$. The exhaust \\ emission tests were performed under actual traffic conditions in the area of Poznań. For the tests a portable exhaust \\ emission analyzers SEMTECH DS and AVL Micro Soot Sensor were used. Based on the obtained values of the emission \\ of CO, NOx and PM the emission indexes were determined that provided information on the excess or non-excess of the \\ unit values of the measured components specified in the EEV standard. The vehicle gas mileage was also determined \\ through the carbon balance method.
}

Key words: heavy-duty truck, exhaust emissions, measurements under actual traffic conditions

\section{Analiza emisyjności samochodu ciężarowego w ruchu miejskim}

W artykule przedstawiono analizę emisyjności samochodu ciężarowego (dystrybucyjnego) o dmc $12000 \mathrm{~kg}$. Badania emisji szkodliwych sktadników spalin wykonano w rzeczywistych warunkach eksploatacji w aglomeracji poznańskiej. Do badań wykorzystano mobilny przyrzą SEMTECH DS oraz mobilny analizator AVL Micro Soot Sensor. Na podstawie uzyskanych wartości emisji CO, NOx i PM wyznaczono wskaźniki emisyjności informujące o przekroczeniu/nieprzekroczeniu limitów emisji jednostkowej mierzonych związów określonych w normie EEV. Wyznaczono także przebiegowe zużycie paliwa, wykorzystując metodę carbon balance.

Słowa kluczowe: samochód ciężarowy, emisja spalin, pomiary w rzeczywistych warunkach eksploatacji

\section{Introduction}

Vehicles playing a key role in the transportation of people and goods are utility vehicles. These include light duty trucks, heavy-duty trucks, buses and coaches. Globally, a great variety of such vehicles are used having different payload that is limited by their gross vehicle weight (GVW). For decades the main source of propulsion of utility vehicles have been diesel engines characterized by high torque allowing an efficient day-to-day operation. As far as the vehicles for the heaviest tasks are concerned ('heavy' segment exceeding 16.000 GVW) their engines are additionally characterized by high engine displacement. This unfortunately results in a low gas mileage (determined in $\mathrm{dm}^{3} / 100 \mathrm{~km}$ ) [1] and high exhaust volume. The above hints that the operation of utility vehicles generates high exhaust emissions and that particular attention should be paid to the reduction of their negative impact on the natural environment. The most impactful, in terms of ecological consequences, is the operation of heavy-duty fleet in the centers of large, highly populated agglomerations (city buses, sanitation vehicles and delivery trucks).

The number of heavy-duty vehicles used in Poland and worldwide grows continuously (Fig. 1). Despite the fact the newly registered vehicles are fitted with technologically and environmentally advanced powertrains (sophisticated aftertreatment systems with a provision for the newest Euro VI standard) it is still necessary to seek ways to reduce the

\section{Wprowadzenie}

Pojazdami, które odgrywają główną rolę w transporcie osób i ładunków są pojazdy użytkowe, w tym samochody dostawcze, ciężarowe i autobusy/autokary. Obecnie na świecie eksploatowanych jest wiele typów takich pojazdów o różnej ładowności, ograniczonej dopuszczalną masą całkowitą pojazdu (dmc). Od wielu dziesięcioleci głównym źródłem napędu pojazdów użytkowych są silniki spalinowe o zapłonie samoczynnym, charakteryzujące się dużą wartością momentu obrotowego, pozwalającego na sprawne wykonywanie codziennych zadań przewozowych. Jeśli chodzi o pojazdy przeznaczone do najcięższych zastosowań - ciężki segment masowy, powyżej 16 tys. $\mathrm{kg} \mathrm{dmc} \mathrm{-} \mathrm{to} \mathrm{ich} \mathrm{jednostki} \mathrm{napędowe}$ charakteryzują się ponadto dużą wartością objętości skokowej. Związane jest z tym, niestety, także duże przebiegowe zużycie paliwa (określane w dm³ $/ 100 \mathrm{~km}$ ) [1] oraz duży wydatek spalin. Z powyższego wynika, że eksploatacja pojazdów użytkowych powoduje dużą emisję zanieczyszczeń do atmosfery i należy zwracać szczególną uwagę na kwestię zmniejszania ich negatywnego oddziaływania na środowisko naturalne. Najbardziej istotne znaczenie w aspekcie ekologicznych skutków eksploatacji pojazdów ciężkich ma emisja związków toksycznych z pojazdów poruszających się po zatłoczonych centrach miast (głównie autobusy miejskie, pojazdy komunalne i dystrybucyjne), gdzie w bliskim otoczeniu tych pojazdów znajduje się duża liczba osób. 


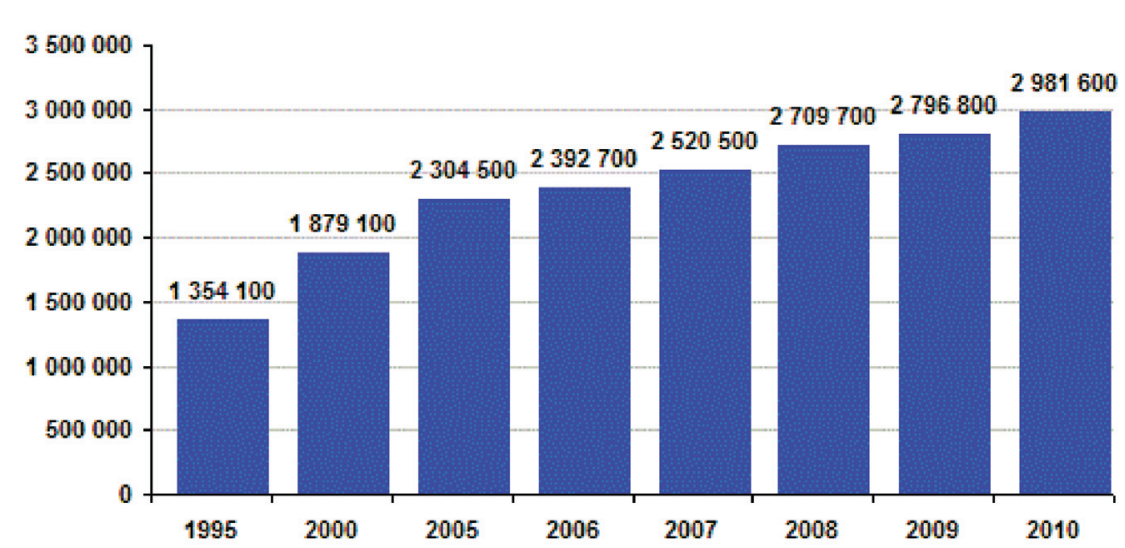

Fig. 1. The number of registered heavy-duty trucks in Poland in the years 1995-2010 [9]

Rys. 1. Liczba zarejestrowanych w Polsce samochodów ciężarowych w latach 1995-2010 [9]

negative impact of these vehicles on the environment. This is possible particularly through on-road tests under actual traffic conditions. Under actual operating conditions, contrary to the laboratory tests conducted in idealized conditions, we can obtain more information that may turn out useful in the optimization of the powertrains in terms of environment protection $[2,3,5]$. Such investigations are invaluable not only for the engine manufacturers but also for the end users in terms of the reduction of the exhaust emissions (mainly $\mathrm{NO}_{x}, \mathrm{PM}$ and $\mathrm{CO}_{2}$ ) and fuel consumption.

\section{Methodology}

On-road exhaust emission tests were performed under actual traffic conditions in the Poznań area (Fig. 2). When selecting the route the authors took into account the necessity of reflecting the actual operation of the heavy-duty trucks
Liczba użytkowanych w Polsce i na świecie samochodów ciężarowych sukcesywnie wzrasta (rys. 1). Mimo że sprzedawane i nowo rejestrowane samochody są wyposażane w coraz bardziej dopracowane konstrukcyjnie i ekologiczne jednostki napędowe (dzięki rozbudowanym układom oczyszczania spalin spełniającym z zapasem najnowszą normę emisji Euro VI), konieczne jest jednak ciągłe poszukiwanie sposobów na ograniczenie niekorzystnego oddziaływania tych samochodów na środowisko. Jest to możliwe zwłaszcza podczas wykonywania badań w warunkach rzeczywistego ruchu po drogach. W rzeczywistej eksploatacji, w porównaniu do badań stanowiskowych prowadzonych $\mathrm{w}$ wyidealizowanych warunkach, można pozyskać bowiem więcej niezbędnych informacji przydatnych do optymalizacji układu napędowego pod względem ograniczenia jego szkodliwego oddziaływania na środowisko naturalne $[2,3$, 5]. Takie badania są cenne nie tylko dla konstruktorów pojazdów i silników, lecz także dla bezpośrednich użytkowników pojazdów mogących przyczynić się w dużym stopniu do zmniejszenia emisji substancji szkodliwych (w tym głównie $\mathrm{NO}_{\mathrm{x}}, \mathrm{PM}$ i $\mathrm{CO}_{2}$ ) oraz zużycia paliwa przez pojazd.

\section{Metodyka badań}

Drogowe badania emisji szkodliwych składników spalin wykonano w rzeczywistych warunkach eksploatacji na od-

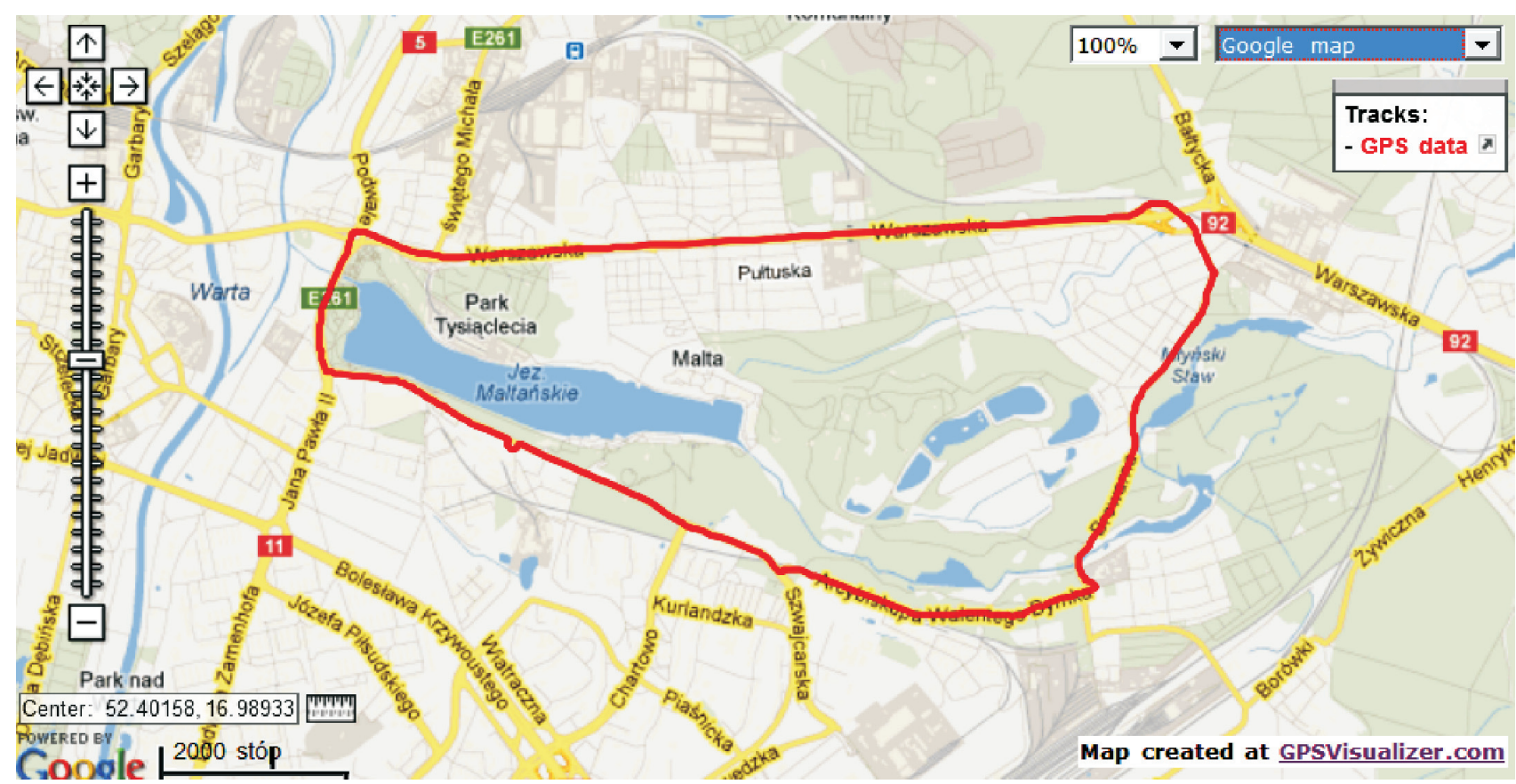

Fig. 2. Test route used for the on-road emission tests of a heavy-duty truck (drawn courtesy of GPSVisualizer.com)

Rys. 2. Trasa badawcza wykorzystana do drogowych badań emisji spalin pojazdu ciężarowego (wykonano na podstawie GPSVisualizer.com) 


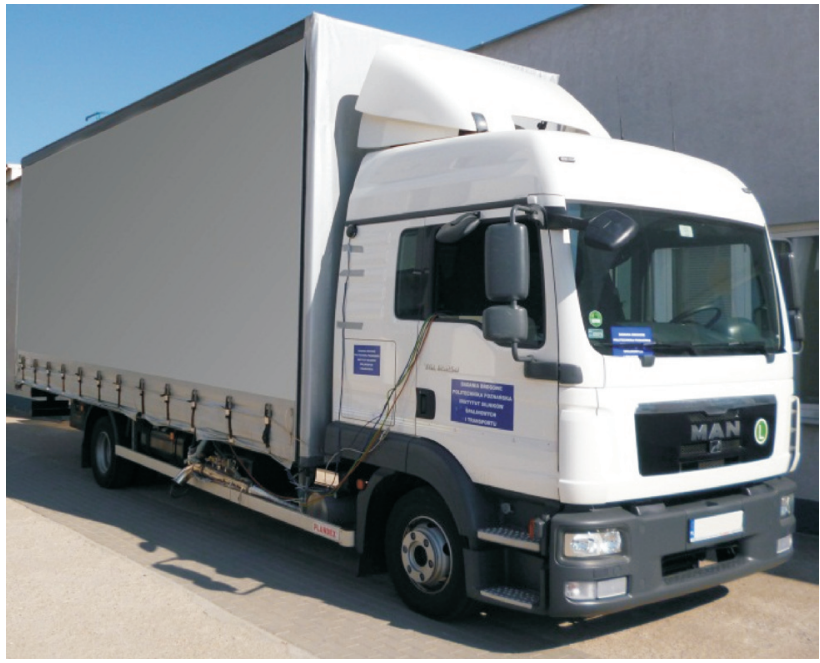

Fig. 3. Truck ready for the on-road exhaust emission test

Rys. 3. Samochód ciężarowy przygotowany do drogowych badań emisji szkodliwych składników spalin

(in city traffic) with particular emphasis on:

- vehicle routes from the city limits to the main intercity roads - extra urban driving,

- vehicle routes between city points - urban traffic.

Additionally, the authors took into account the limitation related to the GVW. The length of the test road portion was $11 \mathrm{~km}$. The tests were conducted in the afternoon at high road congestion.

The object of the research was a delivery truck (Fig. 3). It was fitted with an engine of the displacement of $6871 \mathrm{~cm}^{3}$ and the power output of $184 \mathrm{~kW}$ (Tab. 1). The vehicle was partially loaded so as to reflect the everyday transport routine.

For the measurements of the exhaust emissions (CO, $\mathrm{NO}_{x}, \mathrm{CO}_{2}$ ) and gas mileage a portable SEMTECH DS analyzer (Fig. 4) from the PEMS group (Portable Emissions Measurement System) was used. The concentration of $\mathrm{CO}$ and $\mathrm{CO}_{2}$ was measured by the said measurement device (measurement range $0-20 \%$, accuracy $\pm 3 \%$ ). The concentration of $\mathrm{NO}_{\mathrm{x}}$ was measured with the NDUV (measurement range $0-3000 \mathrm{ppm}$, accuracy $\pm 3 \%$ ). The device was fitted with a standalone weather station obtaining such information as ambient pressure, temperature and air humidity. The authors were thus able to determine the humidity correction factor $\mathrm{K}_{\mathrm{H}}$ used in the measurement of $\mathrm{NO}_{\mathrm{x}}$. The device was also fitted with a GPS module (Global Positioning System) and could communicate with the vehicle OBD [7]. The measurement of the mass exhaust gas flow was realized with a 4" Prandtl pipe flow meter. Discussing the methodology cinku pomiarowym w aglomeracji poznańskiej (rys. 2). Przy wyborze trasy kierowano się możliwością odwzorowania ruchu pojazdów ciężarowych (przeznaczonych do ruchu miejskiego) ze szczególnym uwzględnieniem:

- dojazdu pojazdu od granic miasta do głównych arterii komunikacyjnych - ruch pozamiejski,

- przejazdu pojazdu pomiędzy ośrodkami przemysłowohandlowymi - ruch miejski.

Dodatkowo uwzględniono obowiązujące ograniczenia dotyczące dopuszczalnej masy całkowitej pojazdu. Długość odcinka pomiarowego wyniosła $11 \mathrm{~km}$. Badania przeprowadzono w godzinach popołudniowych przy dużym udziale kongestii drogowych.

Obiektem badawczym był samochód ciężarowy przeznaczonych do ruchu miejskiego - zaliczany do grupy pojazdów dystrybucyjnych (rys. 3). Posiadał on jednostkę napędową o pojemności skokowej $6871 \mathrm{~cm}^{3}$ i mocy $184 \mathrm{~kW}$ (tab. 1). Pojazd obciążono częściowo ładunkiem, tak aby odwzorować codzienne dostarczanie towarów do ośrodków handlowych bądź przemysłowych.

Table 1. Technical specifications of the truck

Tabela 1. Charakterystyka badanego pojazdu ciężarowego

\begin{tabular}{|c|c|}
\hline Powertrain/jednostka napędowa & \\
\hline Ignition system/rodzaj zaplonu & Diesel/ZS \\
\hline $\begin{array}{l}\text { Number of cylinders/liczba cylindrów/ configuration/ } \\
\text { uktad }\end{array}$ & 6 cylinder/rzędowy, straight \\
\hline Engine displacement/pojemność skokowa & $6871 \mathrm{~cm}^{3}$ \\
\hline Maximum power output/moc maksymalna & $184 \mathrm{~kW}(250 \mathrm{KM})$ at/przy $2300 \mathrm{rpm} / \mathrm{obr} / \mathrm{min}$ \\
\hline Maximum torque/maksymalny moment obrotowy & $\begin{array}{l}1000 \mathrm{Nm} \text { in the range from } / w \text { zakresie } \\
1100-1750 \mathrm{rpm} / \mathrm{obr} / \mathrm{min}\end{array}$ \\
\hline Emission standard/norma emisji spalin & EEV \\
\hline Aftertreatment system/uktad oczyszczania & EGR + MAN PM-Kat \\
\hline \multicolumn{2}{|c|}{ Frame/nadwozie } \\
\hline Gross vehicle weight/dopuszczalna masa catkowita & $12000 \mathrm{~kg}$ \\
\hline $\begin{array}{l}\text { Dimensions (length, width, height)/wymiary (dtugość, } \\
\text { wysokość, szerokość) }\end{array}$ & $7800 \times 2550 \times 2950 \mathrm{~mm}$ \\
\hline
\end{tabular}

Do pomiarów emisji $\mathrm{CO}, \mathrm{NO}_{\mathrm{x}}, \mathrm{CO}_{2}$ oraz przebiegowego zużycia paliwa wykorzystano mobilny przyrząd SEMTECH DS (rys. 4) zaliczany do grupy PEMS (Portable Emissions Measurement System). Pomiar stężenia $\mathrm{CO}$ i $\mathrm{CO}_{2}$ odbywał się przy użyciu analizatora (zakres pomiarowy 0-20\%, dokładność $\pm 3 \%$ ). Stężenie $\mathrm{NO}_{\mathrm{x}}$ mierzono analizatorem NDUV (zakres pomiarowy 0-3000 ppm, dokładność $\pm 3 \%$ ). Przyrząd posiadał własną stację meteorologiczną, umożliwiającą pomiar ciśnienia, temperatury oraz wilgotności powietrza. Dzięki temu wyznaczono współczynnik korekcji wilgotności $\mathrm{K}_{\mathrm{H}}$ wykorzystywany przy pomiarach stężenia $\mathrm{NO}_{\mathrm{x}}$. Przyrząd wyposażony był także w moduł GPS (Global Positioning System) oraz umożliwiał komunikację z systemem diagnostycznym pojazdu [7]. Pomiar masowego natężenia przepływu spalin odbywał się przy użyciu przepływomierza o średnicy 4" działającego na zasadzie rurki Prandtla. Omawiając metodykę pomiaru gazowych składników spalin, 


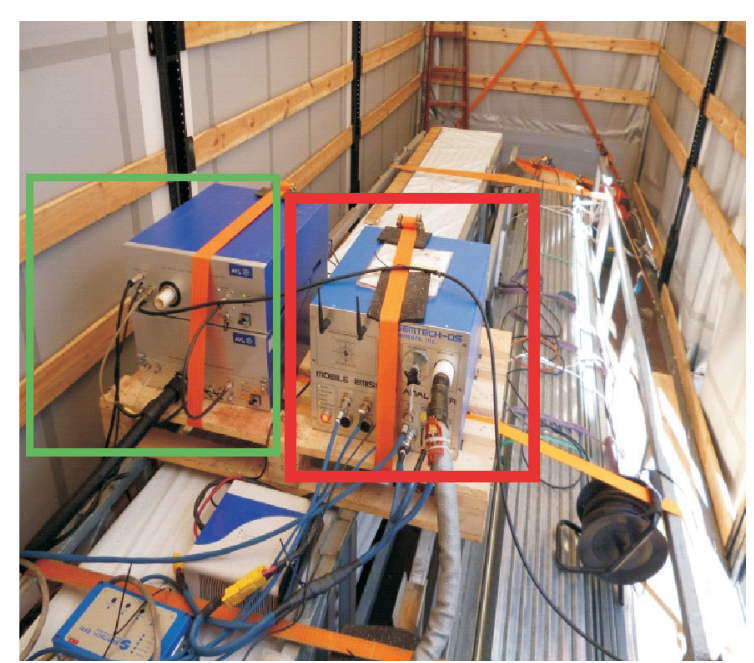

Fig. 4. Measurement equipment installed in the truck bed (SEMTECH DS - red frame, AVL 483 MSS - green frame)

Rys. 4. Aparatura pomiarowa zainstalowana w przestrzeni ładunkowej samochodu ciężarowego (przyrzad SEMTECH DS zaznaczono czerwona ramka, a analizator AVL 483 MSS ramka zielona)

of the measurement of the gaseous exhaust components we must note that the emission of $\mathrm{HC}$ was not measured. The experience of the authors of this paper in testing of EEV compliant heavy-duty vehicles tells that the powertrains of these vehicles generate negligible amounts of $\mathrm{HC}$ (within the measurement error).

For the measurement of the particulate matter the authors used AVL 483 Micro Soot Sensor, a portable analyzer measuring the concentration of the PM in diluted exhaust (Fig. 4). The analyzer utilizes the photo-acoustic method based on the measurement of the carbon part of the particle. This method consists in significant absorption of the modulated laser light by the soot particles. This results in an alternate heating and chilling of the medium gas in the measurement chamber. A sound wave is thus generated that is recorded by the microphones [6].

\section{The results of the conducted exhaust emission measurements}

Based on the measured values of $\mathrm{CO}, \mathrm{NO}_{\mathrm{x}}, \mathrm{CO}_{2}$ and the information pulled from the vehicle OBD and GPS, time density characteristics were determined in the ranges of the vehicle speed and acceleration and the engine speed and load. In the same ranges the characteristics of the exhaust emissions (measured with second by second resolution) were determined.

The operating time share of the vehicle determined in the ranges of speeds and accelerations was divided into three main areas: the first one was for the stopped vehicle (at the same time this was the greatest operating time share $-49 \%$ ), the second one was for the speeds of $2-6 \mathrm{~m} / \mathrm{s}$ at the acceleration of $0-0.6 \mathrm{~m} / \mathrm{s}^{2}$, which was $26 \%$ of the operating time and the third one was for the highest speeds $(14-20 \mathrm{~m} / \mathrm{s})$ constituting $11 \%$ of the operating time (Fig. $5 \mathrm{a}$ ). Such a distribution of the operating time of the vehicle is related to the engine work fields in the ranges of the engine speed and load (Fig. należy wspomnieć, że nie dokonano pomiaru emisji HC. Doświadczenie autorów tego artykułu w dziedzinie badań pojazdów ciężarowych spełniających normę emisji spalin EEV wskazuje, że jednostki napędowe tych pojazdów emitują pomijalnie małe wartości HC (mieszczące się w granicy błędu pomiaru).

Do pomiaru cząstek stałych wykorzystano mobilny analizator AVL 483 Micro Soot Sensor, który umożliwiał ciągły pomiar stężenia cząstek stałych w rozcieńczonych spalinach (rys. 4). Analizator wykorzystuje metodę fotoakustyczną umożliwiającą pomiar części węglowej cząstki stałej. Ta metoda polega na znacznej absorpcji modulowanego światła laserowego przez cząstki sadzy. Skutkuje to okresowym (przemiennym) ogrzewaniem i chłodzeniem gazu nośnego, co wywołuje zmianę ciśnienia w komorze pomiarowej. Powstaje w ten sposób fala dźwiękowa, która jest rejestrowana przez mikrofony [6].

\section{Wyniki przeprowadzonych badań emisji spalin}

$\mathrm{Na}$ podstawie zmierzonych wartości emisji $\mathrm{CO}, \mathrm{NO}_{\mathrm{x}}$, $\mathrm{CO}_{2}$ oraz informacji odczytanych $\mathrm{z}$ układu diagnostycznego pojazdu i układu GPS, wyznaczono charakterystyki udziału czasu pracy w przedziałach prędkości i przyspieszenia pojazdu oraz prędkości obrotowej wału korbowego i obciążenia silnika pojazdu. W tych samych przedziałach wyznaczono charakterystyki emisji sekundowej mierzonych związków.

Udział czasu pracy pojazdu określony w przedziałach prędkości i przyspieszenia można podzielić na trzy główne obszary: pierwszy przypadł dla postoju pojazdu i jednocześnie stanowił największy udział całkowitego czasu pracy $-49 \%$, drugi przypadł w zakresie prędkości 2-6 m/s przy przyspieszeniu $0-0,6 \mathrm{~m} / \mathrm{s}^{2}$ i stanowił $26 \%$ czasu pracy oraz trzeci - w zakresie największych prędkości (14-20 $\mathrm{m} / \mathrm{s}$ ), stanowiąc $11 \%$ czasu pracy (rys. 5a). Taki rozkład udziału czasu pracy odniesiony do pojazdu związany jest $\mathrm{z}$ rozkładem pól pracy jednostki napędowej w przedziałach prędkości obrotowej wału korbowego i obciążenia (rys. 5b). Największy udział czasu pracy w tych przedziałach przypadł w zakresie $600-800 \mathrm{obr} / \mathrm{min}$ przy $100-200 \mathrm{~N} \cdot \mathrm{m}$ i stanowił $66 \%$ całkowitego czasu pracy. Drugim znaczącym obszarem pracy jednostki napędowej był zakres średnich prędkości obrotowych wału korbowego silnika (1000-1600 obr/min) przy obciążeniu 300-600 N·m. Obszar ten stanowił $25 \%$ całkowitego czasu pracy i wynikał bezpośrednio z charakterystyki pracy silników pojazdów ciężarowych. Uzyskanie takich rozkładów udziału czasu pracy wynikało z charakterystyki odcinka pomiarowego oraz z dużego udziału kongestii drogowych.

W odniesieniu do pojazdu największe natężenie emisji CO wystąpiło dla maksymalnych przyspieszeń pojazdu w zakresie prędkości $4-8 \mathrm{~m} / \mathrm{s}$ i $14-16 \mathrm{~m} / \mathrm{s}$ (rys. 6a). Takie ukształtowanie emisji sekundowej CO mogło wynikać ze zwiększonej dawki paliwa koniecznej do uzyskania przez pojazd dużych przyspieszeń. Chwilowe zwiększenie dawki paliwa powoduje wzbogacenie mieszanki paliwowo-powietrznej dostarczanej do komory spalania, czego jednym ze skutków jest wystąpienie zjawiska spalania niezupełnego. 
a)

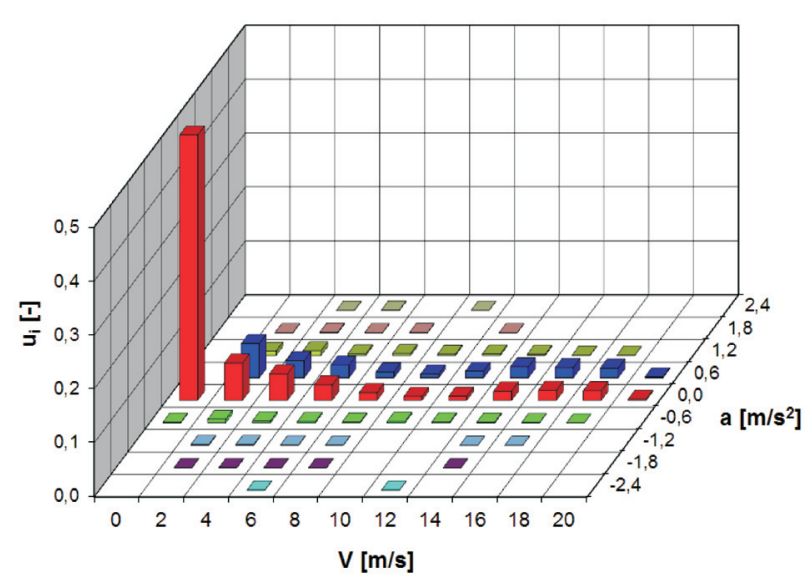

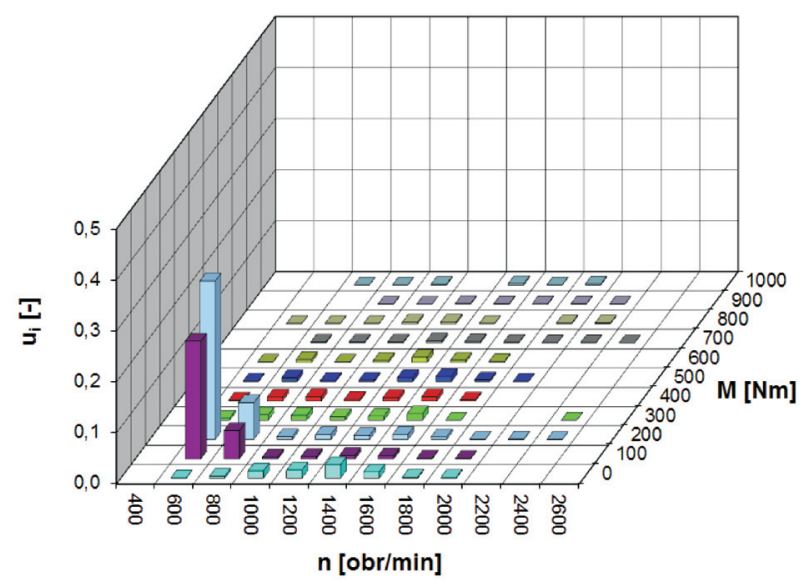

Fig. 5. Characteristics of the operating time share in the ranges: a) vehicle speed and acceleration, b) engine speed and load

Rys. 5. Charakterystyka udziału czasu pracy w przedziałach: a) prędkości i przyspieszenia pojazdu, b) prędkości obrotowej wału korbowego i obciażenia silnika

$5 b)$. The greatest operating time share in these ranges was for $600-800 \mathrm{rpm}$ at $100-200 \mathrm{~N} \cdot \mathrm{m}$ and constituted $66 \%$ of the total operating time. Another significant work field of the engine was the range of medium engine speeds (1000-1600 $\mathrm{rpm}$ ) at the load of $300-600 \mathrm{~N} \cdot \mathrm{m}$. This area constituted $25 \%$ of the total operating time and resulted directly from the characteristics of operation of heavy-duty vehicle engines. The obtainment of such operating time share distributions resulted from the characteristics of the measurement road portion and a high road congestion.

The greatest $\mathrm{CO}$ emission rate occurred for the maximum vehicle accelerations in the speed range of 4-8 m/s and 14-16 $\mathrm{m} / \mathrm{s}$ (Fig. 6a). Such a CO emission could have resulted from an increased dose of fuel needed for the vehicle to reach high accelerations. A momentary increase in the fuel dose results in a richer air fuel mixture fed to the combustion chamber the consequence of which is incomplete combustion. The a)

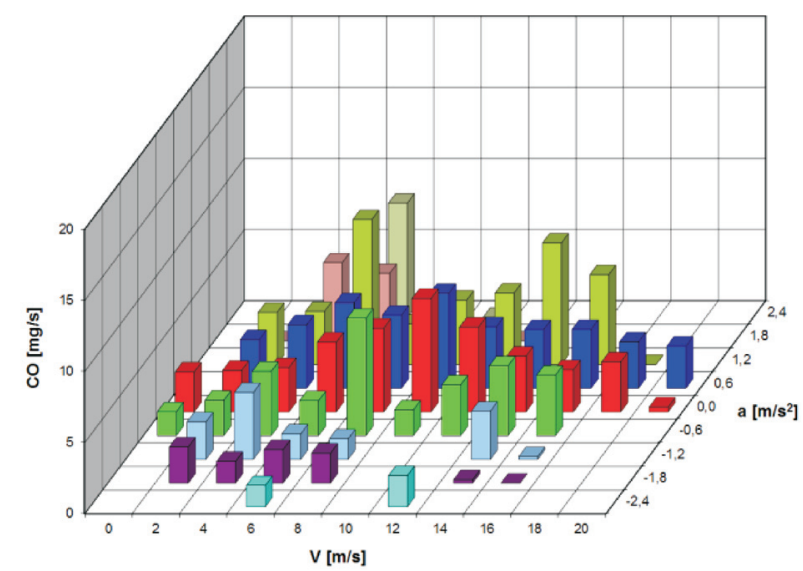

Uzyskany rozkład emisji sekundowej $\mathrm{CO}$ w przedziałach prędkości obrotowej wału korbowego i obciążenia silnika - największa wartość emisji CO wystąpiła dla prędkości 1800-2400 obr/min i dla maksymalnego zakresu obciążenia 700-1000 N·m (rys. 6b) - może wskazywać na wystąpienie tego zjawiska.

W przedziałach prędkości i przyspieszenia pojazdu największe średnie natężenie emisji $\mathrm{NO}_{\mathrm{x}}$ wystąpiło dla przyspieszenia $0,6 \mathrm{~m} / \mathrm{s} 2 \mathrm{w}$ całym zakresie prędkości (rys. 7a). Zwrócono także uwagę, że największy udział emisji sekundowej $\mathrm{NO}_{\mathrm{x}}$ wystąpił w przedziale średnich prędkości pojazdu $(10-14 \mathrm{~m} / \mathrm{s}) \mathrm{W}$ zakresie przyspieszeń $0-1,8 \mathrm{~m} / \mathrm{s}^{2}$ i stanowił $48 \%$ całkowitej emisji uzyskanej przez pojazd podczas trwania testu. Tak duży udział emisji sekundowej $\mathrm{NO}_{\mathrm{x}}$ przy średnich prędkościach wynikał z charakterystyki pracy zamontowanego w pojeździe układu SCR - najwyższy stopień konwersji $\mathrm{NO}_{\mathrm{x}}$ w reaktorze katalitycznym SCR wy-

b)

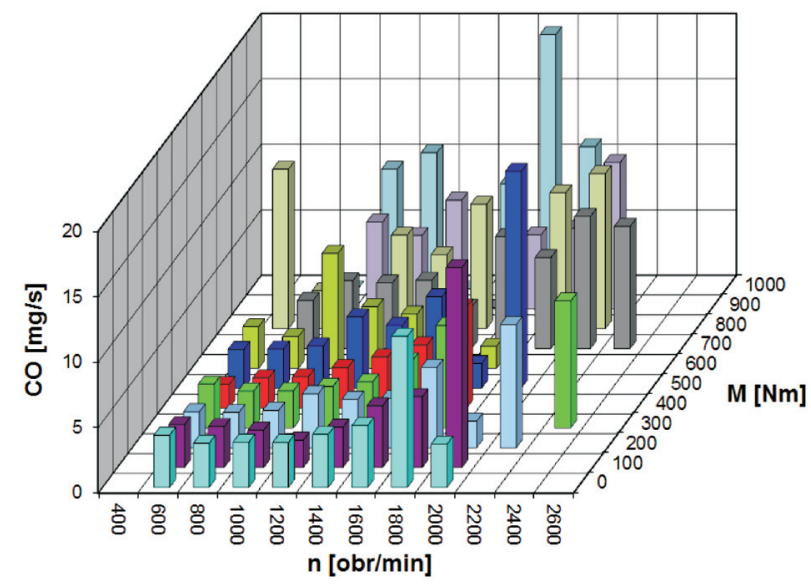

Fig. 6. The characteristics of the emission of $\mathrm{CO}$ (second by second measurement resolution) in the ranges: a) vehicle speed and acceleration, b) engine speed and load

Rys. 6. Charakterystyka emisji sekundowej CO w przedziałach: a) prędkości i przyspieszenia pojazdu, b) prędkości obrotowej wału korbowego i obciażenia silnika 
a)

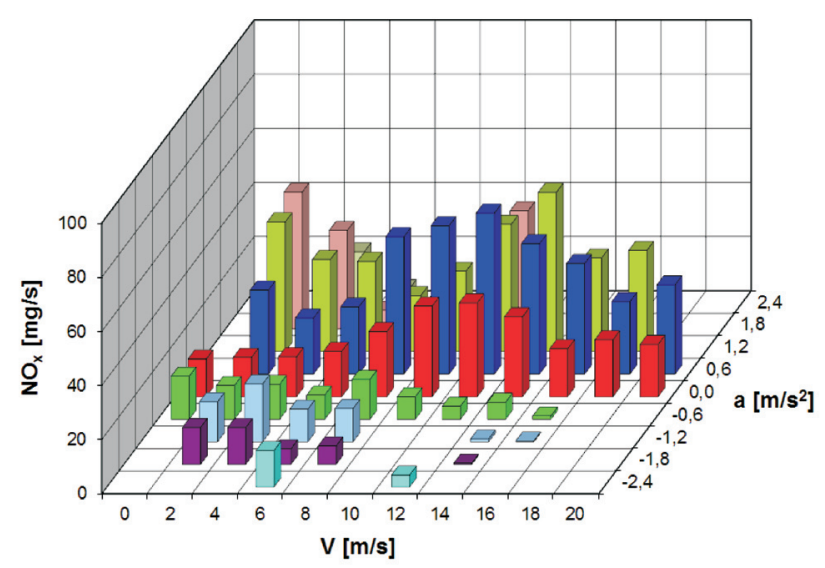

b)

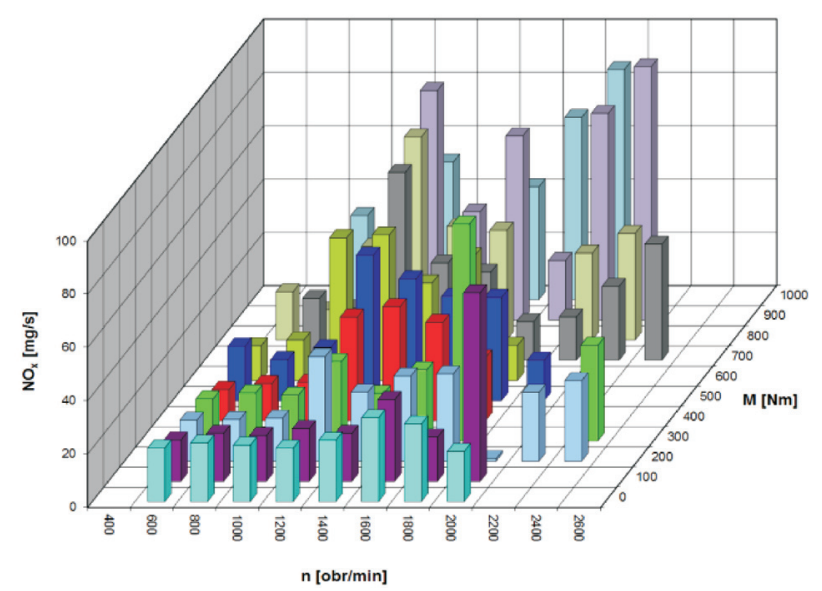

Fig. 7. The characteristics of the emission of $\mathrm{NO}_{x}$ (second by second measurement resolution) in the ranges: a) vehicle speed and acceleration, b) engine speed and load

Rys. 7. Charakterystyka emisji sekundowej $N_{x}$ w przedziałach: a) prędkości i przyspieszenia pojazdu, b) prędkości obrotowej wału korbowego i obciażenia silnika

obtained distribution of the $\mathrm{CO}$ emission in the ranges of engine speed and load (the greatest $\mathrm{CO}$ emission level occurred for 1800-2400 rpm and maximum engine load $700-1000 \mathrm{~N} \cdot \mathrm{m}-$ Fig. 6b) may indicate the occurrence of the said phenomenon of incomplete combustion.

In the ranges of vehicle speed and acceleration the greatest $\mathrm{NO}_{\mathrm{x}}$ emission rate occurred for the acceleration of 0.6 $\mathrm{m} / \mathrm{s}^{2}$ in the whole speed range (Fig. 7a). It was observed that the greatest share of the $\mathrm{NO}_{\mathrm{x}}$ emission (measured with second by second resolution) occurred in the range of medium vehicle speeds $(10-14 \mathrm{~m} / \mathrm{s})$ in the range of accelerations of $0-1.8 \mathrm{~m} / \mathrm{s}^{2}$ and constituted $48 \%$ of the total emission generated by the vehicle during the test. Such a great share of the emission (measured with second by second resolution) at medium speeds resulted from the characteristics of the SCR system fitted in the vehicle (the greatest $\mathrm{NO}_{\mathrm{x}}$ conversion rate

a)

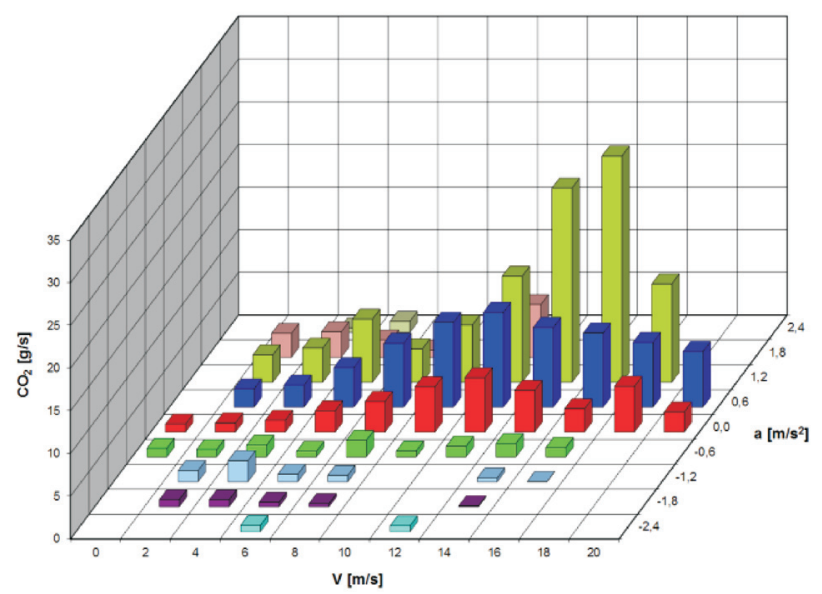

stępuje wtedy, gdy temperatura spalin przekracza $200^{\circ} \mathrm{C}$. W odniesieniu do parametrów pracy silnika największa emisja sekundowa $\mathrm{NO}_{\mathrm{x}}$ wystąpiła dla maksymalnych obciążeń z zakresu 800-1000 N·m (rys. 7b).

Przebieg natężenia emisji $\mathrm{CO}_{2}$ odniesiony do pojazdu oscylował w zakresie przyspieszeń $0-1,8 \mathrm{~m} / \mathrm{s}_{2}$ (rys. $8 \mathrm{a}$ ). Największa wartość emisji sekundowej $\mathrm{CO}_{2}$ wystąpiła w obszarze maksymalnych prędkości (14-16 m/s) przy zakresie przyspieszeń $0-1,6 \mathrm{~m} / \mathrm{s}^{2}$ i wyniosła $27 \mathrm{~g} / \mathrm{s}$. Sumaryczna wartość emisji w tym przedziale stanowiła $45 \%$ całkowitej emisji $\mathrm{CO}_{2}$ uzyskanej przez pojazd podczas badań. W odniesieniu do jednostki napędowej (rys. 8b) emisja sekundowa $\mathrm{CO}_{2}$ wzrastała wraz ze wzrostem prędkości obrotowej wału korbowego i obciążenia silnika, osiągając najwyższą wartość $26 \mathrm{~g} / \mathrm{s}$ (przedział $2200 \mathrm{obr} / \mathrm{min}$ przy $900 \mathrm{~N} \cdot \mathrm{m}$ ). Uzyskanie takich rozkładów natężenia emisji $\mathrm{CO}_{2}$ odniesionych do po-

b)

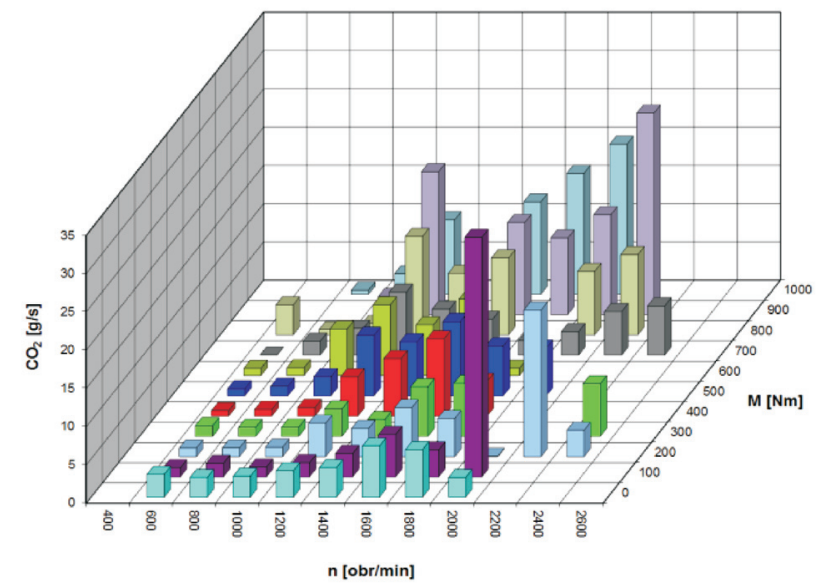

Fig. 8. The characteristics of the emission of $\mathrm{CO}_{2}$ (second by second measurement resolution) in the ranges: a) vehicle speed and acceleration, b) engine speed and load

Rys. 8. Charakterystyka emisji sekundowej $\mathrm{CO}_{2}$ w przedziałach: a) prędkości i przyspieszenia pojazdu, b) prędkości obrotowej wału korbowego i obciażenia silnika 
in an SCR takes place when the exhaust gas temperature exceeds $200{ }^{\circ} \mathrm{C}$. In relation to the engine parameters the greatest $\mathrm{NO}_{\mathrm{x}}$ emission occurred for the maximum loads $800-1000 \mathrm{Nm}$ (Fig. 7b).

The course of the $\mathrm{CO}_{2}$ emission rate for the vehicle oscillated around the accelerations of $0-1.8 \mathrm{~m} / \mathrm{s}^{2}$ (Fig. $8 \mathrm{a}$ ). The greatest value of the emission of $\mathrm{CO}_{2}$ (measured with second by second resolution) occurred for the maximum speeds $(14-16 \mathrm{~m} / \mathrm{s})$ at the range of accelerations of $0-1,6 \mathrm{~m} / \mathrm{s}^{2}$ and was $27 \mathrm{~g} / \mathrm{s}$. The collective value of the emission in this range constituted $45 \%$ of the total $\mathrm{CO}_{2}$ emission generated by the vehicle during the tests. In relation to the engine (Fig. 8b) the emission of $\mathrm{CO}_{2}$ grew as the engine speed and load increased reaching the highest value of $26 \mathrm{~g} / \mathrm{s}$ (2 $200 \mathrm{rpm}$ at $900 \mathrm{Nm}$ ). The obtainment of such distributions of $\mathrm{CO}_{2}$ emission rate for the vehicle and the engine mainly resulted from the characteristics of the measurement road portion (significant changes in acceleration), which led to an increased energy demand by the engine during driveoff.

Knowing the values of the emission of $\mathrm{CO}, \mathrm{NO}$, $\mathrm{CO}_{2}$ measured with the second by second resolution and the length of the test road portion the values of the road emission of the above components were determined (Fig. 9). For the determination of the road emission of PM its measured concentration, exhaust mass flow and the covered distance were used. Based on the road emissions of $\mathrm{CO}$ and $\mathrm{CO}_{2}$ gas mileage was determined through the carbon balance method:

$$
\mathrm{Q}=\frac{0.1155}{\rho_{\mathrm{pal}}}\left[(0.866 \cdot \mathrm{HC})+(0.426 \cdot \mathrm{CO})+\left(0.273 \cdot \mathrm{CO}_{2}\right)\right](1)
$$

where: $\mathrm{Q}$ - the value of gas mileage $\left[\mathrm{dm}^{3} / 100 \mathrm{~km}\right], \mathrm{HC}, \mathrm{CO}$, $\mathrm{CO}_{2}$-average values of the road emission $[\mathrm{g} / \mathrm{km}], \rho_{\mathrm{pal}}-$ fuel density at normal temperature $15^{\circ} \mathrm{C}\left[\mathrm{g} / \mathrm{cm}^{3}\right]$.

In equation (1) the element related to the average road emission of $\mathrm{HC}$ has been omitted because, as mentioned earlier, the $\mathrm{HC}$ emission was not measured. On the selected test route the truck had a gas mileage of $28.2 \mathrm{dm}^{3} / 100 \mathrm{~km}$. This value was mainly influenced by high road congestion resulting in a relatively low average vehicle speed, which in this case was $12 \mathrm{~km} / \mathrm{h}$.

\section{Conclusions}

The investigations presented in this paper were conducted under non-standard conditions. That is why, for the evaluation of the obtained results the authors adopted a reference point - the EEV emission standard. The emission indexes were determined defined as the multiple of the excess/nonexcess of the unit emission limits of the individual exhaust components as specified by the EEV standard $[4,8]$ :

$$
\mathrm{k}_{\mathrm{j}}=\frac{\mathrm{E}_{\text {rzecz }, j}}{\mathrm{E}_{\text {norma }, j}}
$$

jazdu i silnika wynikało przede wszystkim z charakterystyki odcinka pomiarowego - duże zmiany przyspieszeń - co wiązało się ze zwiększonym zapotrzebowaniem energetycznym jednostki napędowej podczas ruszania pojazdu.

Znając wartość emisji sekundowej $\mathrm{CO}, \mathrm{NO}_{x}, \mathrm{CO}_{2}$ oraz długość odcinka pomiarowego, wyznaczono wartości emisji drogowej powyższych związków (rys. 9). Dla PM - do wyznaczenia emisji drogowej - wykorzystano zmierzoną

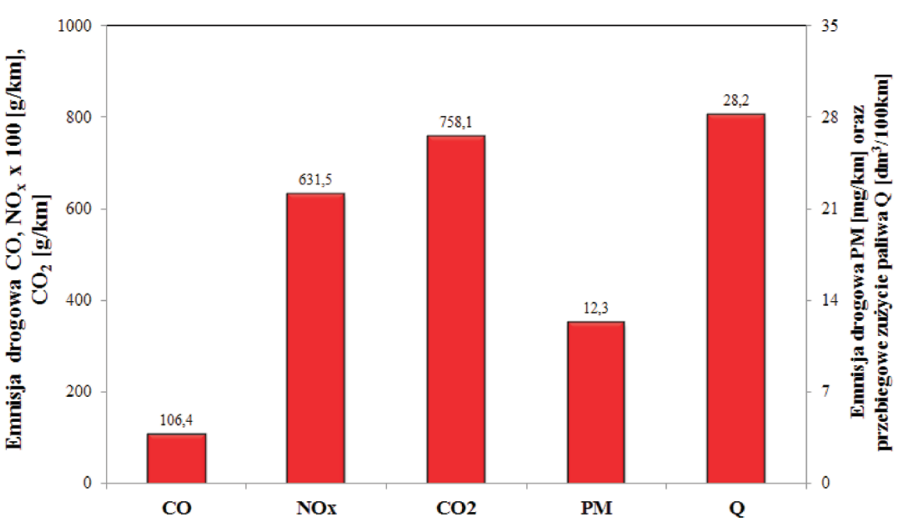

Fig. 9. Road emissions of $\mathrm{CO}, \mathrm{NO}_{x}, \mathrm{CO}_{2}, \mathrm{PM}$ and gas mileage Rys. 9. Wartość emisji drogowej $\mathrm{CO}, \mathrm{NO}_{x}, \mathrm{CO}_{2}, \mathrm{PM}$ oraz przebiegowego zużycia paliwa

ich koncentrację, masowe natężenie przepływu spalin oraz dystans. Na podstawie wartości emisji drogowej $\mathrm{CO}$ i $\mathrm{CO}_{2}$ wyznaczono przebiegowe zużycie paliwa pojazdu ciężarowego na badanej trasie, opierając się na metodzie bilansu węgla (carbon balance) - wzór (1), gdzie: Q - wartość przebiegowego zużycia paliwa $\left[\mathrm{dm}^{3} / 100 \mathrm{~km}\right], \mathrm{HC}, \mathrm{CO}$, $\mathrm{CO}_{2}$-średnie wartości emisji drogowej $[\mathrm{g} / \mathrm{km}], \rho_{\text {pal }}-$ gęstość paliwa w normalnej temperaturze $15^{\circ} \mathrm{C}\left[\mathrm{g} / \mathrm{cm}^{3}\right]$.

$\mathrm{W}$ równaniu (1) pominięto człon dotyczący średniej emisji drogowej HC, gdyż, jak wspomniano, nie mierzono emisji HC. Na wyznaczonej trasie badawczej pojazd ciężarowy uzyskał przebiegowe zużycie paliwa $28,2 \mathrm{dm}^{3} / 100$ $\mathrm{km}$. Wpływ na taką wartość zużycia paliwa miał duży udział kongestii drogowych, który skutkował relatywnie niską średnią prędkością uzyskaną przez pojazd, a która wyniosła $12 \mathrm{~km} / \mathrm{h}$.

\section{Podsumowanie}

Przedstawione w artykule badania wykonano w warunkach niestandardowych, dlatego do oceny uzyskanych wyników autorzy przyjęli punkt odniesienia w postaci norm emisji EEV. Wyznaczono wskaźniki emisyjności, które zdefiniowano jako krotność przekroczenia/nieprzekroczenia limitów emisji jednostkowej poszczególnych składników spalin określonych przez normę EEV [4, 8] - wzór (2), gdzie: $\mathrm{E}_{\text {rzecz,j }}$ - średnia emisja jednostkowa uzyskana w warunkach rzeczywistych $[\mathrm{g} /(\mathrm{kW} \cdot \mathrm{h})], \mathrm{E}_{\text {norma, }}$ - emisja jednostkowa normatywna według normy EEV $[\mathrm{g} /(\mathrm{kW} \cdot \mathrm{h})]$.

Wyznaczone wskaźniki emisyjności stanowią kryterium oceny wpływu pojazdu ciężarowego na środowisko natu- 
where: $\mathrm{E}_{\mathrm{rzecz,j}}$ - average unit emission obtained under actual operating conditions $[\mathrm{g} /(\mathrm{kW} \cdot \mathrm{h})], \mathrm{E}_{\text {norma }, \mathrm{j}}$ - normative unit emission as per the EEV standard $[\mathrm{g} /(\mathrm{kW} \cdot \mathrm{h})]$.

The determined emission indexes are a criterion for the evaluation of the impact of heavy-duty vehicles on the natural environment. The analysis of the obtained results (Fig. 10) confirms that:

a)In relation to the ESC test the unit emission:

- CO constitutes $48 \%$ of the value specified in the stan-dard,

- $\mathrm{NO}_{\mathrm{x}}$ constitutes $214 \%$ of the value specified in the standard,

- PM constitutes $42 \%$ of the value specified in the stan-dard,

b)In relation to the ETC test the unit emission:

- CO constitutes $24 \%$ of the value specified in the stan-dard,

- $\mathrm{NO}_{\mathrm{x}}$ constitutes $214 \%$ of the value specified in the standard,

- PM constitutes $42 \%$ of the value specified in the standard.

The above values indicate that the $\mathrm{NO}_{\mathrm{x}}$ emission from the heavy-duty truck in the city traffic (delivery truck) under actual operating conditions significantly exceeds the levels specified in the EEV standard. For the other exhaust components the emission is much smaller than that specified in the said standard. The authors of this paper are aware that referring the obtained results to the EEV standard can only be approximate due to a different course of the emission test for compliance with the EEV standard.

In the context of the conducted investigations it is noteworthy to draw attention to the draft of the Euro VI standard for heavy-duty vehicles. This draft assumes a development of a methodology utilizing PEMS (Portable Emissions Measurement System) that can be used to measure the exhaust emission from these vehicles under actual conditions of their operation. In order to develop proper testing methodology of the vehicles, measurements of a larger group of vehicles need to be carried out under different traffic conditions. It is, thus justified to continue research based on the methodology presented in this paper. The extension of the homologation procedures by the said tests should further reduce the negative impact of vehicles on the environment.

\footnotetext{
Abbreviations/Skróty i oznaczenia

a Acceleration/przyspieszenie

GVW/DMC Gross Vehicle Weight/dopuszczalna masa catkowita

EEV Enhanced Environmentally Friendly Vehicle/pojazd przyjazny środowisku

EGR Exhaust Gas Recirculation/recyrkulacja spalin

$\mathrm{E}_{\text {norma }}$ Emissions rate obtained in the EEV standard/emisja normatywna

$\mathrm{E}_{\text {rzecz }}$ Emissions rate obtained under actual conditions/emisja rzeczywista
}

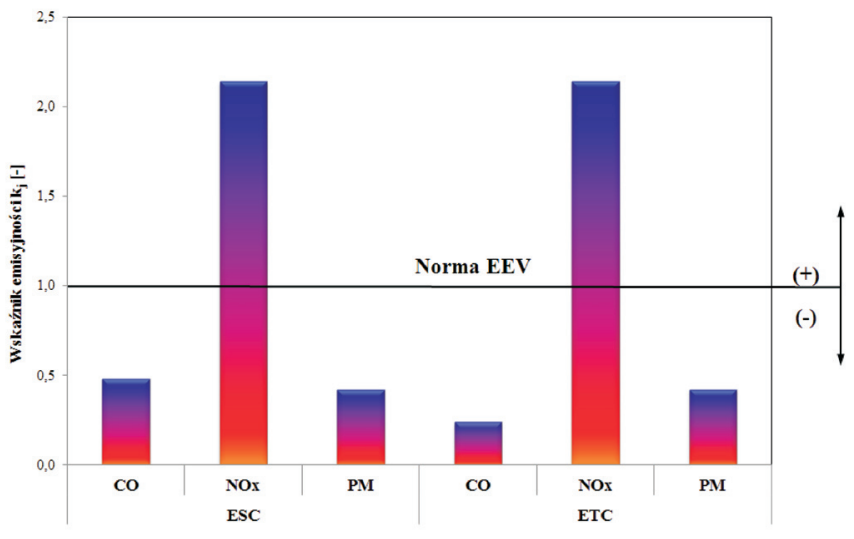

Fig. 10. The emission indexes for the heavy-duty vehicle determined based on the exhaust emissions measured under actual operating conditions

Rys. 10. Wskaźniki emisyjności dla samochodu ciężarowego wyznaczone na podstawie badań emisji spalin $w$ rzeczywistych warunkach eksploatacji

ralne. Analizując otrzymane wskaźniki (rys. 10), można stwierdzić, że:

a) w odniesieniu do testu ESC emisja jednostkowa:

- CO stanowi 48\% wartości określonej w normie,

- $\mathrm{NO}_{\mathrm{x}}$ stanowi 214\% wartości określonej w normie,

- PM stanowi 42\% wartości określonej w normie,

b) w odniesieniu do testu ETC emisja jednostkowa:

- CO stanowi 24\% wartości określonej w normie,

- NO stanowi 214\% wartości określonej w normie,

- PM stanowi 42\% wartości określonej w normie.

Powyższe wartości wskazują, że emisja badanego samochodu ciężarowego przeznaczonego do ruchu miejskiego (pojazd dystrybucyjny) w rzeczywistych warunkach eksploatacji w zakresie $\mathrm{NO}_{\mathrm{x}}$ odbiega istotnie od poziomów emisji określonych w normie EEV. Z kolei dla pozostałych składników spalin jest ona znacząco mniejsza niż przewidziana w wyżej wymienionej normie. Autorzy tego artykułu zdają sobie sprawę, że odnoszenie uzyskanych wyników do normy EEV może mieć charakter jedynie przybliżony, z uwagi na odmienny przebieg testu emisji na zgodność $\mathrm{z}$ normą EEV.

W kontekście wykonanych badań warto zwrócić uwagę na projekt normy emisji spalin Euro VI dla ciężkich pojazdów samochodowych, który zakłada opracowanie metodyki wykorzystania aparatury PEMS do szacowania emisji spalin tych pojazdów w rzeczywistych warunkach ich eksploatacji. Aby opracować poprawną metodykę badań pojazdów, należy przeprowadzić pomiary dla większej liczby pojazdów w zróżnicowanych warunkach ruchu. Zasadne zatem jest prowadzenie dalszych badań opartych na metodyce przedstawionej w niniejszym artykule. Rozszerzenie procedur homologacyjnych o te badania powinno spowodować dalsze ograniczenie negatywnego wpływu pojazdów na środowisko naturalne.

Paper reviewed/Artykut recenzowany 
GPS Global Positioning System/globalny system wyznaczania pozycji

$\mathrm{k} \quad$ Emissions indexes/wskaźnik emisji

M Engine torque/moment obrotowy silnika

$\mathrm{n} \quad$ Engine speed/prędkość obrotowa watu korbowego silni$k a$

NDIR Non-Dispersive Infrared/niedyspersyjny analizator na podczerwień
NDUV Non-Dispersive Ultraviolet/niedyspersyjny analizator na ultrafiolet

PEMS Portable Emissions Measurement System/mobilny system do pomiary emisji spalin

SCR Selective Catalytic Reduction/selektywna redukcja katalityczna

u Share/wspótczynnik udziału

V Vehicle speed/prędkość pojazdu

\section{Bibliography/Literatura}

[1] Cea E., Larrodé E., Gallego J.: Emissions and Consumption Reductions in Heavy-Duty Vehicles by Means Optimized Engines and Fuel Systems. SAE Technical Paper Series 200801-0882.

[2] Gao Y., Checkel M.D.: Emission Factors Analysis for Multiple Vehicles Using an On-Board, In-Use Emissions Measurement System. SAE Technical Paper Series 2007-01-1327.

[3] Merkisz J., Fuć P.: The Exhaust Emission from Light Duty Vehicles in Road Test in Urban Traffic. International Powertrains, Fuels \& Lubricants Meeting, May 2010, Rio de Janeiro, Brazil, 2010. SAE Paper 2010-01-1558.

Prof. Jerzy Merkisz, DSc., DEng. - Professor in the Faculty of Working Machines and Transportation at Poznan University of Technology.

Prof. Jerzy Merkisz - profesor na Wydziale Maszyn Roboczych i Transportu Politechniki Poznańskiej.

e-mail:jerzy.merkisz@put.poznan.pl

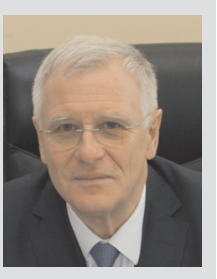

Piotr Paweł Molik, MSc, Eng. - PhD student at the Faculty of Working Machines and Transportation at Poznan University of Technology.

Mgr inż. Piotr Pawel Molik - doktorant na Wydziale Maszyn Roboczych i Transportu Politechniki Poznańskiej.

e-mail:piotr.c.molik@doctorate.put.poznan.pl

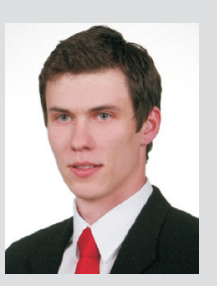

Dawid Nijak, MSc, Eng. - specialist in Transport Policy Office in Department of Municipality and Housing Administration at Poznań City Hall.

Mgr inż. Dawid Nijak - specjalista w Oddziale Polityki Transportowej Wydziału Gospodarki Komunalnej i Mieszkaniowej Urzędu Miasta Poznania. e-mail:dawid_nijak@vp.pl

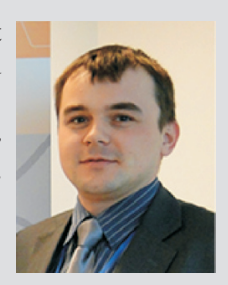

Mateusz Nowak, MSc, Eng. - PhD student in the Faculty of Working Machines and Transportation at Poznań University of Technology.

Mgr inż. Mateusz Nowak-doktorant na Wydziale Maszyn Roboczych i Transportu Politechniki Poznańskiej.

e-mail: mateusznowakpp@o2.pl

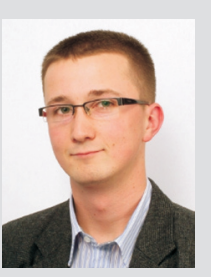

[4] Merkisz J., Pielecha J.: The on-road exhaust emissions chracteristics of SUV vehicles fitted with diesel engines. Combustion Engines 2/2011 (145).

[5] Rubino L., Bonnel P., Hummel R., Krasenbrink A., Manfredi U., De Santi G.: On-road Emissions and Fuel Economy of Light Duty Vehicles using PEMS: Chase-Testing Experiment. SAE Technical Paper Series 2008-01-1824.

[6] AVL Micro Soot Sensor, Transient High Sensitive Soot Measurement, AVL, 2010.

[7] SEMTECH®-DS On Board, In-Use Emissions Analyzer, Manual, Michigan 2007.

[8] www.delphi.com/pdf/emissions/Delphi_HD.pdf

[9] www.stat.gov.pl

Miłosław Kozak, DEng. - doctor in the Faculty of Working Machines and Transportation at Poznan University of Technology.

Dr inż. Mitoslaw Kozak - adiunkt na Wydziale Maszyn Roboczych i Transportu Politechniki Poznańskiej.

e-mail:miloslaw.kozak@put.poznan.pl

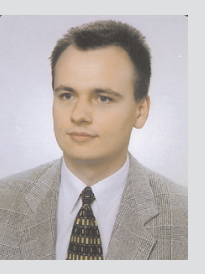

Maciej Andrzejewski, MSc, Eng. - PhD student at the Faculty of Working Machines and Transportation at Poznan University of Technology.

Mgr inż. Maciej Andrzejewski - doktorant na Wydziale Maszyn Roboczych i Transportu Politechniki Poznańskiej.

e-mail:maciej.andrzejewski@doctorate.put.poznan.pl

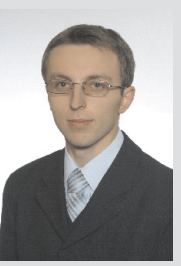

Łukasz Rymaniak, MSc, Eng. - PhD student in the Faculty of Working Machines and Transportation at Poznań University of Technology.

Mgr inż. Lukasz Rymaniak - doktorant na Wydziale Maszyn Roboczych i Transportu Politechniki Poznańskiej.

e-mail: rymaniak.lukasz@onet.eu

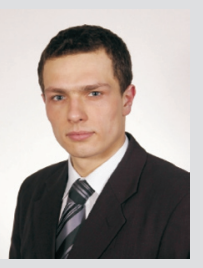

Andrzej Ziółkowski, MSc, Eng. - PhD student in the Faculty of Working Machines and Transportation at Poznań University of Technology.

mgr inż. Andrzej Ziótkowski - doktorant na Wydziale Maszyn Roboczych i Transportu Politechniki Poznańskiej.

e-mail:andrzej.wo.ziolkowskidoctorate.put.poznan.pl

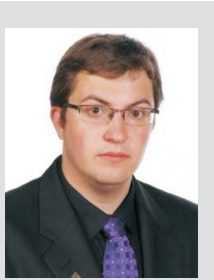

